Abstracta Iranica

Revue bibliographique pour le domaine irano-aryen

Volume 32-33 | 2013

Comptes rendus des publications de 2009-2010

\title{
Panagiotis P. Iossif, Catharine C. Lorber. The Cult of Helios in the Seleucid East
}

\section{Vito Messina}

\section{(2) OpenEdition \\ 1 Journals}

\section{Electronic version}

URL: http://journals.openedition.org/abstractairanica/40523

DOI: 10.4000/abstractairanica.40523

ISSN: 1961-960X

Publisher:

CNRS (UMR 7528 Mondes iraniens et indiens), Éditions de l'IFRI

\section{Printed version}

Date of publication: 1 December 2013

ISSN: 0240-8910

\section{Electronic reference}

Vito Messina, "Panagiotis P. Iossif, Catharine C. Lorber. The Cult of Helios in the Seleucid East », Abstracta Iranica [Online], Volume 32-33 | 2013, document 176, Online since 01 July 2016, connection on 02 October 2020. URL : http://journals.openedition.org/abstractairanica/40523 ; DOI : https:// doi.org/10.4000/abstractairanica.40523

This text was automatically generated on 2 October 2020 .

Tous droits réservés 


\title{
Panagiotis P. Iossif, Catharine $\mathrm{C}$. Lorber. The Cult of Helios in the Seleucid East
}

\author{
Vito Messina
}

\section{REFERENCES}

Panagiotis P. Iossif, Catharine C. Lorber. « The Cult of Helios in the Seleucid East ».

Topoi, 16/1, 2009, p. 19-42.

1 Amongst the many representations of Seleucid sovereigns on their coins or on official and unofficial seals are the portrayals of kings that clearly link them to Helios or a solar god. In these representations, which do not seem to go back prior to the accession of Seleucus IV, the king's head "radiates", sometimes floral patterns. This should probably be interpreted as a symbol of prosperity. The iconography of the king should, of course, be related to the political situation, as many studies on self-representation in several regions of the Seleucid Empire have shown. Nonetheless, the origin and purpose of such representations remain unclear. The present article presents the evidence from numismatic, epigraphic and sphragistic sources about the evolving, complicated policy of the Seleucids with respect to eastern cults, in particular the close, manifest connection of certain sovereigns (at least starting from the reign of Seleucus IV) with eastern solar gods but mediated by the figures of the Greek gods Helios and Apollo. This connection reflects the Seleucid kings' need of legitimacy in the ancient Near East. The authors' allusion to the Iranian notion of xwarənah, which, since the Achaemenid period, refers to royal legitimacy, is worth mentioning and worthy of further study. 


\section{AUTHORS}

\section{VITO MESSINA}

Università di Torino 